Елена В. Горбова

Российский государственный педагогический университет им А. И. Герцена

Институт иностранных языков

Кафедра романской филологии

elena-gorbova@yandex.ru
УДК 811.161.1'366.58'37

https://doi.org/10.18485/slavistika.2019.23.1.2

оригинални научни рад

примљено 10.04.2019.

прихваћено за штампу 16.05.2019.

\title{
ДВУХКОМПОНЕНТНАЯ МОДЕЛЬ РУССКОГО ВИДА: ПОЛОЖЕНИЯ, ПРЕДСКАЗАНИЯ, ПОДТВЕРЖДЕНИЯ*
}

В статье предложена двухкомпонентная модель русского вида, альтернативная традиционной (слово)классифицирующей модели. Первым ее компонентом является морфологический механизм имперфективирующей суффиксации префигированных глаголов, имеющий словоизменительный характер: pac-кры-ть - pac-кры-вa-mb, однако суженную сферу действия. В качестве второго компонента выступает акциональность (лексический вид) с максимально широкой сферой действия, равной объему глагольного класса. Акциональность (во взаимодействии со значимыми элементами внешнего контекста) обеспечивает функционирование и характеризацию в терминах (им)перфектива моноаспективов и биаспективов, оставшихся за пределами словоизменительного грамматического вида. Кроме того, сформулированы обобщения и предсказания, вытекающие из двухкомпонентной модели, а также предложена их верификация на основе данных литературы.

Ключевые слова: русский язык, вид (аспект), грамматическая категория, теоретическая модель, словоизменение, акциональность, моноаспектив, биаспектив, приставочный перфектив, вторичный имперфектив.

This article proposes a two-component model of the Russian Aspect, as an alternative to the traditional (word)classifying model. The first component of the model is a morphological mechanism of the imperfectivizing suffixation of prefixed verbs that is inflectional (ras-kry- $\mathrm{t}^{\mathrm{PFV}}$ - ras-kry-va-

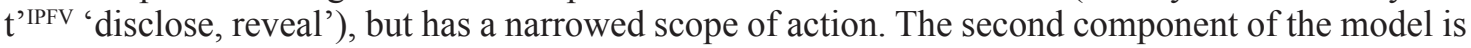
the actionality (lexical aspect) with a maximal scope, equal to the whole verb class. Actionality (in interaction with significant elements of the external context) enables the functioning and perfective/ imperfective characterization of mono- and biaspectives, which remain outside of the inflectional grammatical Aspect. In addition, some generalizations and predictions arising from the two-component model are formulated, and their verification based on literature data is proposed.

Key words: Russian, Aspect, grammatical category, theoretic model, inflection, actionality, monoaspective, biaspective, prefixal perfective, secondary imperfective.

\footnotetext{
* Исследование поддержано грантом РФФИ 19-012-00143 А «Суффиксальная имперфективация приставочных перфективов в современном русском языке». 
Научная теория есть просто математическая модель, построенная нами для описания результатов наблюдений: она существует только у нас в голове. Поэтому не имеет смысла спрашивать, что же реально - действительное время или время мнимое. Важно лишь, какое из них более подходит для описания.

Стивен Хокинг. Краткая история времени: От большого взрыва до черных дыр. Москва: Изд-во АСТ, 2018. C. 168.

\section{1. Вводные замечания}

Целью данной статьи является представление альтернативной, по отношению к традиционной, представленной, например, в РГ-80 (Шведова (ред.) 2005), модели русского вида, названной вслед за К. Смит, см. (Smith 1991/1997, Смит 1998), двухкомпонентной. Альтернативная модель имеет те же составляющие - аспектуально релевантные (под)классы глагольной лексики, что и традиционная, однако оказывается существенно иной: словоизменительной, с более узкой (чем вся глагольная лексика) сферой действия ее словоизменительного компонента, использующей понятия не только грамматического, но и лексического вида (акциональности), типологически более предсказуемой.

Работа имеет следующую структуру. В разделе 1.1 представлен созданный на основе анализа литературы по русскому виду перечень аспектуально значимых глагольных (под)классов, обнаруживающих различия по отношению к противопоставлению СВ (перфектив) НСВ (имперфектив). В разделе 1.2 дается краткое изложение традиционной модели русского вида как (слово)классифицирующей категории. В разделе 2 приводятся взятые из научной литературы данные о соотношении парных и непарных глаголов. Раздел 3 содержит краткое изложение предлагаемой двухкомпонентной модели вида, грамматическим компонентом которой выступает словоизменительная трактовка оппозиции $\mathrm{CB} \sim \mathrm{HCB}$. После схематического очерка предлагаемой модели, в разделе 4 формулируются вытекающие из нее предсказания. Раздел 5 посвящен изложению взятых из литературы эмпирических фактов, которые, как представляется, служат подтверждением предложенной модели. В заключительном 6-м разделе подводятся итоги и формулируются перспективы.

\section{1. Перечень аспектуальных (под)классов русского глагола}

Начнем с обзора аспектуально охарактеризованных в терминах известной дихотомии СВ (перфектив) НСВ (имперфектив) (под)классов русских глаголов.

1. Непроизводные глаголы (симплексы; определение см. в (Plungjan 2017 171)): спать, стоять, молчать, вертеть, купить, дать, пасть; в большинстве случаев эти глаголы функционируют как $\mathrm{HCB}_{1}{ }_{1}^{1}$, но есть немногочислен-

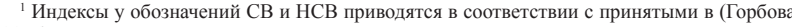
2017б)
Двухкомпонентная модель русского вида: положсения, предсказания, подтверэсения

ные $\mathrm{CB}_{1}$, а также $\mathrm{CB} / \mathrm{HCB}$; т. е. симплексы - это моноаспективы ((im)perfectiva tantum) и биаспективы (двувидовые глаголы)

2. Приставочные перфективы - глаголы с одним префиксом: nереспать, npoстоять, отмолчаться, отвертеть, закупить, продать; т. е. это «вторичные перфективы», условно обозначаемые как $\mathrm{CB}_{2}$; образуемые в результате множественной префиксации «полиперфективы» типа пере-за-пис-ыва-ть в этот класс не включены; описание алгоритма множественной префиксации см. в (Татевосов 2009, 2013, 2015).

3. Вторичные имперфективы $\left(\mathrm{HCB}_{2}\right)$ как результат вторичной имперфективации: nepecыnáms (всю последнюю неделю), простаивать (каждый раз в очереди по нескольку часов), отмалчиваться, отверчивать, закупать, продават (приведены формы $\mathrm{HCB}_{2}$ от данных в предыдущем пункте $\mathrm{CB}_{2}$ ).

4. Imperfectiva tantum (моноаспективы) различных морфологических типов (как производные, так и непроизводные): cnamb, негодовать; частично пересекаются с классом 1.

5. Perfectiva tantum (моноаспективы) различных морфологических типов: лечь, очутиться; частично пересекаются с классом 1.

6. Биаспективы (двувидовые глаголы) различных морфологических типов: женить, акцентировать; частично пересекаются с классом 1.

7. «Аспектуально неустойчивые» и «полуторавидовые» глаголы (терминь Н. В. Перцова (Перцов 2001) и И. Б. Иткина (Иткин 2014)) различных морфологических типов: разнообразить, образовать и полонить, стяжать; частично пересекаются с классом $1^{2}$

\section{2. Традиционная модель русского вида}

Традиционной будем считать модель, представленную в РГ-80. Ее можно свести к следующим основным положениям.

Сфера действия категории максимально широка - вся глагольная лексика языка, ср: «[к]атегорией вида охватываются все глаголы» (Там же: 583).

Русский вид - (слово)классифицирующая категория, ср.: «видовая пара - это противопоставление разных глаголов, находящихся между собой в отношениях словообразовательной мотивации»; «[к]атегория вида является категорией несловоизменительной» (Там же: 584 )

Помимо периферийных супплетивных пар типа говорить - сказать, выделяются два основных типа видовых пар: 1) формируемые путем (префиксальной) перфективации (делать - сделать) и 2) формируемые путем (суффиксальной) имперфективации (переписать - переписыьвать) (Там же: 585).

Признается, что у части русских глаголов нет видовых показателей, ср.: «есть глаголы, у которых значение вида никак формально не выражено, оно может быть

${ }^{2}$ Диахронически неустойчивы, отмечаются колебания в диапазоне от полной моноаспективности к равновесной биаспективности. Хорошей иллюстрацией такой вариабельности и развития является глагол пасть, диахронический портрет которого представлен в (Plungjan 2017)

Славистика XXIII/1 (2019) 
установлено только по общему смыслу высказывания. .. Такие глаголы называются двувидовыми» (Там же) (здесь используется синонимичный термин биаспективы)

Признается, что поскольку «[к]атегория вида охватывает все глаголы, но не все глаголы формируют видовые пары», имеются несоотносительные по виду глаголы (Там же: 584); т. е. (im)perfectiva tantum, или моноаспективы: спать, соснуть.

Глаголами perfectiva tantum в рамках традиционной модели являются, в основном, приставочные или суффиксальные дериваты (закричать, крикнуть).

Для обсуждения возможностей двух теоретических моделей русского вида традиционной и альтернативной - полезно оценить представленность соотносительных и несоотносительных по виду глаголов, чему будет посвящен раздел 2.

\section{2. «Удельный вес» моно- и биаспективов}

Для оценки занимаемого моно- и биаспективами места в глагольной лексике возьмем данные из трех публикаций - (Мучник 1971; Перцов 2001; Андросюк 2015)

Источником материала для исследования (Мучник 1971) явился словарь Д. Н. Ушакова, «а также разнообразные факты литературного языка разных жанров» (Мучник 1971: 112). Объем проанализированного материала составил около 9 тысяч глаголов (Там же)

И. П. Мучник выделяет 3 группы глаголов:

1. Парные глаголы («глаголы, образующие соотносительные видовые корреляции» (Мучник 1971: 112); важно отметить, что в их число не входят пары, образованные приставочной перфективацией) - $64 \%$.

2. Биаспективы («глаголы, выступающие в различных видовых значениях, но не обладающие морфологическими средствами для обнаружения во всех случаях видовых различий» (Там же)) - 5\%.

3. Моноаспективы («глаголы, не образующие соотносительных видовых корреляций: а) только совершенного вида: очутился, возгордился; б) только несовершенного вида: вращался, бездействовал» (Там же)) - 31\%.

Итак, несколько огрубляя, по данным (Мучник 1971) парные и непарные (суммарно моно- и биаспективы) русские глаголы находятся в соотношении 2 к 1 (64\% против 36\%).

Обратимся к данным из работы (Перцов 2001). Источником материала в этом случае послужил словарь А. А. Зализняка (Зализняк 1977). Для исследования, как указывает автор, использовалась программная среда STARLING C. А. Старостина, с помощью которой была создана база данных. Из 97333 записей в базе данных оказалось 27697 глаголов (28,46\% от общего числа записей), из которых:

соотносительных по виду (без префиксальных пар) : 61,34\% от всех глаголов; двувидовых глаголов (биаспективы) : $3,15 \%$ от всех глаголов;

одновидовых глаголов (моноаспективы) : $35,51 \%$ от всех глаголов (Перцов 2001: 132).
Двухкомпонентная модель русского вида: положсения, предсказания, подтвержсения 49

Таким образом, на другом источнике языкового материала и с другой величиной выборки (не 9, а почти 28 тысяч глаголов) был получен близкий по соотношению парных и непарных глаголов результат: $61,34 \%$ на $38,66 \%$ (впрочем, со сдвигом на три процентных пункта в пользу непарных).

Полученные данные послужили основанием для следующего заявления: «В классической литературе можно встретить утверждение о «сплошной парности» русского глагола (см., например, (Пешковский 1956: 106). <..> Если не рассматривать префиксальные пары в качестве нормальных видовых, придется признать его полную несостоятельность...» (Перцов 2001: 132).

Примечательно и то, что по причине значительности доли одновидовых глаголов, по критерию «коррелятивность» («наличие (почти) у всех единиц коррелятов / наличие большого числа единиц без коррелятов» (Перцов 2001: 132)) русский вид характеризуется автором как словообразовательная (а не словоизменительная) категория (Там же).

В работе (Андросюк 2015), посвященной изучению функционирования биаспективов $^{3}$ в современном русском языке и основанной на материалах Национального корпуса русского языка (http://www.ruscorpora.ru), а также языка Интернета (Яндекс и Рамблер), вопрос о доле биаспективов среди русских глаголов не ставится. Однако это исследование предоставляет нам данные о количестве биаспективов в абсолютных цифрах и их распределении по двум классам: славянским по происхождению и заимствованным глаголам. Из общего количества в 1028 единиц (Андросюк 2015: 33) 65 биаспективов (6\% от общего количества) были охарактеризованы как славянские (Там же: 22), и более 1000 - как заимствованные (Там же: 27). Кроме того, к значимым выводам относятся следующие положения. Во-первых, о «разной степени двувидовости: одни более тяготеют к $\mathrm{CB}$, другие - к НCВ, и только некоторые употребляются одинаково часто в обоих видах» ${ }^{4}$ (Там же: 33 ). Во-вторых, о том, что «класс двувидовых глаголов в целом не сокращается» (Там же), поскольку переход глаголов из класса биаспективов в класс моноаспективов происходит существенно более медленными темпами (всего 16 из составленного с учетом мнения ряда словарей перечня в 1028 единиц), чем пополнение класса биаспективов за счет неперфективирующей, сохраняющей видовую амбивалентность, префиксации (переквалифичировать, деиентрализовать, дооборудовать и др.) (Там же).

35иаспективы в (Андросюк 2015) включают в себя «полуторавидовые» глаголы И. Б. Иткин (Иткин 2014) и «аспектуально нестабильные» глаголы Н. В. Перцова (Перцов 2001: 122). То есть это весь спектр непарных глаголов, способных хотя бы в части своей парадигмы функционировать и как CB, и как НCB, но не (im)perfectiva tantum (моноаспективы). Изучение вопрос о преобладании перфективных или имперфективных употреблений таких гл

${ }^{4}$ Собственно, введенное И. Б. Иткиным в (Иткин 2014) понятие полуторавидовых глаголов апеллирует именно к таким случаям - с неодинаковой для разных словоформ в парадигме предпочтительностью их употребления как перфектива или имперфектива. 


\section{3. Двухкомпонентная модель описания вида русского глагола}

Данная модель является альтернативой традиционной модели, описанной в разделе 1.1. Совершенно ожидаемо она «собирается» из тех же компонентов, т. е. тех же (под)классов русской глагольной лексики. Однако она обнаруживает серьезные отличия от традиционной (слово)классифицирующей модели. Кроме того, двухкомпонентная модель позволяет, как мы постараемся показать, сформулировать верифицируемые предсказания. В разделе 5 мы, по возможности кратко, остановимся на каждом из этих положений.

\section{1. Общая характеристика двухкомпонентной модели русского вида}

Предлагаемая альтернативная модель русского вида является двухкомпонентной в смысле (Smith 1991/1997, Смит 1998). Один из ее компонентов (главный) - имеет словоизменительный характер. Он основан на морфологическом механизме суффиксации и обладает сферой действия, не охватывающей все глаголы. Второй - это акциональность глагольной лексики, или лексический вид, характеризующий глаголы в терминах состояний, (не)предельных процессов, событий и т. под., с максимально широкой сферой действия. Первый компонент принадлежит области явной грамматики (имеет показатели) и является основным. Именно он обеспечивает русскому виду характер грамматической словоизменительной категории. Второй относится области скрытой грамматики (не имеет показателей), однако значим для категорий грамматики явной, а также оказывается очень существенным фактором для аспектуальной характеризации по (им)перфективности для глаголов, остающихся за пределами сферы действия первого компонента - словоизменительного вида.

Как уже было сказано, сфера действия вида как словоизменения в предлагаемой модели оказывается более узкой, чем в традиционной модели вида Словоизменением охвачены исключительно приставочные перфективы (класс 2 из раздела 1.1) и образованные от них суффиксацией (показатели $-(u / b l / e) в a-$, реже -a-) вторичные имперфективы (класс 3 из раздела 1.1 ): $\mathrm{CB}_{2} \sim \mathrm{HCB}_{2}$. То есть это случаи типа от-кpы-ть $\left(\mathrm{CB}_{2}\right) \sim$ om-кpbl-вa-mb $\left(\mathrm{HCB}_{2}\right) ;$ npu-om-кpbl-mb (полиперфектив) npu-от-кры-ва-ть $\left(\mathrm{HCB}_{2}\right)$.

Приставочные перфективы как производные от симплексов (класс 1 из раздела 1.1) дериваты преимущественно являются результатом телисизирующего воздействия префиксов-ограничителей - показателей одной из граммем вторичного аспекта по (Плунгян 2011: 401-402). Поскольку префикс при вторичной имперфективации наследуется от (приставочного) перфектива, лексическая семантика в рамках данного морфологического механизма оказывается не затронутой. При этом суффикс имперфективации вводит в словоформу исключительно грамматическую семантику имперфектива: либо в виде итеративности (многократности), либо дуративности (в окне наблюдения - срединная стадия единичной ситуации, см. (Плунгян 2011:394)). Таким образом, перфектив и образуемый от него имперфектив признаются аспектуальными формами одной лексемы, а соответствующий морфологический механизм - основным механизмом видообразования.
Двухкомпонентная модель русского вида: положсения, предсказания, подтверэсения

Принимая во внимание то обстоятельство, что суффиксальная имперфективация регулярна ${ }^{5}$, мы приходим к выводу о том, что в рамках данной сферы действия категория вида - это типичная словоизменительная грамматическая категория, обладающая свойствами обязательности и регулярности.

Вся остальная глагольная лексика, т. е. моноаспективы и биаспективы различной морфосинтаксической и деривационной природы (классы 1 и 4-7 из раздела 1.1), остается за пределами грамматического (словоизменительного) вида. Ее функционирование определяется взаимодействием вида лексического (акциональности) глагольной лексемы, т. е. второго компонента модели (см. анализ семантики и акциональности $\mathrm{HCB}_{1}$ и $\mathrm{HCB}_{2}$ в (Горбова 2015: 25-31), а также (Горбова 2017б: 40-41), с синтагматическим и парадигматическим контекстом, определяющими аспектуальное значение глагола в высказывании (типология контекста из (Горбова 2017а: 28-29)).

\section{2. (Под)классы глагольной лексики в рамках обсуждаемой модели}

Пройдем еще раз по классам русской глагольной лексики из раздела 1.1 , попутно обозначая их место в обсуждаемой теоретической модели.

(Единожды) префигированные перфективы (класс 2) и вторичные имперфективы (класс 3), формально различаясь отсутствием / наличием суффикса имперфективации, образуют словоизменительную видовую парадигму: om-мblmb ${ }^{\mathrm{CB}}$ $\sim$ om-мbl-вa-mb ${ }^{\mathrm{HCB} 2}$. При этом сами префигированные перфективы (класс 2) по отношению к производящим их симплексам (класс 1), cp. om-мыть ${ }^{\mathrm{CB} 2} \longleftarrow$ мыть $^{\mathrm{HCB} 1}$, -делать $^{\mathrm{CB} 2} \leftarrow$ делать $^{\mathrm{HCB} 1}$, про-дать $^{\mathrm{CB} 2} \leftarrow$ дать $^{\mathrm{CB} 1}$, яВляются самостоятельными производными лексемами, результатом словообразования.

Биаспективы (классы 6 и часть класса 1; по (Андросюк 2015: 33) их 1028 , по (Мучник 1971) их доля - 5\%, по (Перцов 2001) - 3,15\%) рассматриваются в предлагаемой модели не как периферия, а как норма и аналог глагольной лексики видового языка с типично словоизменительным видом (испанский, английский) или невидового языка (немецкий). К ним примыкают (у некоторых авторов, как в (Андросюк 2015), - с ними пересекаются) так называемые «полуторавидовые» (Иткин 2014) и «аспектуально нестабильные» (Перцов 2001: 122) глаголы (класс 7).

Моноаспективы (классы 4 и 5, частично класс 1; напомним, что по (Мучник 1971 ) их доля $-31 \%$, по (Перцов 2001) - 35,51\%) отличаются от биаспективов тем, что демонстрируют устойчивые предпочтения глаголов к (им)перфективности, предположительно обусловленные их акциональностью (лексическим видом): ситуации, концептуализованные как события, тяготеют к перфективности; а концептуализованные как состояния или непредельные процессы, - к имперфективности.

Положение моноаспективов остается стабильным до тех пор, пока не включается механизм: а) префигирования, б) последующей суффиксальной импер-

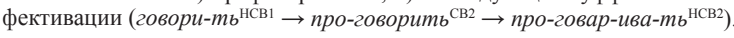

${ }^{5}$ С уровнем регулярности от 81 до 97\% по данным анализа имперфективируемости прои $y$-перфективов, см. (Горбова 2019).

Славистика XXIII/1 (2019) 
В этом смысле показательно поведение заимствованных глаголов на $-u(з u)$ ровать: для них возможно движение от статуса моно- или биаспектива к образованию полной видовой парадигмы, например: информирова-ть $\rightarrow$ проинформирова-ть ${ }^{\mathrm{CB} 2} \rightarrow$ про-информиров-ьва-ть ${ }^{\mathrm{HCB} 2}$, см. (1).

(1) Надоела. Сказанула... Я умоляю тебя приходить сюда почаще и проинформировывать нас о каждой стадии ее болезни. (http://usagi-chan.narod.ru/ $\mathrm{gb} / 106)$

Рассмотрим моноаспективы по отдельности. Функционально определенный класc imperfectiva tantum (класс 4) в большинстве своем, по-видимому, конституируется симплексами (класс 1), которым по тем или иным причинам не свойственна биаспектуальность (иметь, жить), а также частью отыменных образований (белить, белеть, учительствовать, безобразничать).

Столь же функционально определенный класc perfectiva tantum (класс 5), с единичными симплексами из класса 1 (лечь), в основном конституируется дериватами-семельфактивами (с суффиксами -ну-, -ану-: прыс-ну-ть, руб-ану-ть), а также некоторыми отыменными образованиями (про-иляn-и-ть $\leftarrow$ иляпа, y-вол-и-ть $\leftarrow$ воля)

К этому же функциональному классу относятся полиперфективы типа $н a-$

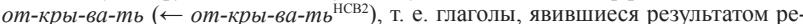
ализации множественной префиксации и не допускающие третичной имперфективации (о запрете на нее см. (Татевосов 2009, 2013, 2015)). Имеется в виду невозможность образования *на-от-кpы-вы-ва-mb ${ }^{\text {нсв3 }} \leftarrow$ на-от-кры-ва-ть. Данные о количестве таких принципиально не имперфективируемых перфективов в русистике на данный момент отсутствуют, что, очевидно, объясняется тем, что сам запрет на третичную имперфективацию, равно как и алгоритмы множественной префиксации, были сформулированы всего десять лет назад. Отметим также, что перфективы, явившиеся результатом множественной префиксации, практически не представлены в словарях, поскольку являются низкочастотными, конструируемыми в процессе порождения речи, единицами.

\section{4. Обобщения и предсказания двухкомпонентной модели вида русского глагола}

Поскольку одна теоретическая модель получает преимущества перед другой (другими) только в том случае, если обладает лучшими возможностями делать предсказания относительно функционирования моделируемого объекта (ср.: «всякое теоретическое положение... может быть первоначально выдвинуто из эстетических или метафизических соображений, но затем должно пройти реальную проверку - позволяет ли оно делать предсказания, согласующиеся с наблюдениями» (Хокинг 2018: 165)), перейдем к изложению обобщений и предсказаний двухкомпонентной модели вида. Следующим этапом будет сравнение сделанных утверждений (предсказаний) с наблюдениями над языковым материалом (раздел 5).

(1) В силу известного в общей морфологии более высокого положения суффикса по отношению к префиксу в иерархии конфиксов, см. (Мельчук 2001: 171), ожидаемым будет преимущество суффиксального форманта по сравнению с префиксальным при формообразовании в области аспекта (вида), что находит отражение в большей регулярности суффиксального показателя и, следовательно, в его большей предрасположенности к формированию словоизменительной грамматической категории при достаточном уровне грамматикализации; одновременно ожидается меньшее семантическое варьирование аспектуальных форм, образованных суффиксацией, по сравнению с образованными префиксацией (шире - при участии превербов в смысле (Аркадьев 2015: 16-17)).

(2) Глагольная префиксация, изначально возникающая как средство лексической (модифицирующей лексическую семантику) деривации (часто - на основе пространственных значений), не может обладать и не обладает регулярностью ни со стороны формы, ни со стороны содержания (в силу множественности используемых префиксов, обладающих собственной семантикой) и не ведет: а) к обязательной телисизации префигированного деривата (возникновения акционального значения соотнесенности с пределом); б) к обязательной перфективации деривата как результата грамматикализации телисизации; в) к обязательному образованию грамматического противопоставления деривационно связанных симплекса и образованного от него префиксального (превербного) деривата.

(3) При контактном взаимодействии языков глагольная префиксация может быть заимствована языком-реципиентом, однако при этом ожидается следующее: а) в языке-реципиенте префиксация будет обладать более низким уровнем грамматикализации по сравнению с языком-донором; б) заимствование префиксации (как исходно словообразовательного явления) в общем случае не зависит от заимствования суффиксальных аспектуальных механизмов, в силу чего при наличии в языке-доноре обоих морфологических механизмов каждый из них может заимствоваться отдельно, изолированно от другого.

(4) При наличии в языке высокограмматикализованных суффиксальных дериватов, то есть образований, получивших статус аспектуальных глагольных форм, непроизводная глагольная лексика языка (глаголы-симплексы), а также префиксальные глагольные образования, по тем или иным причинам не подвергшиеся суффиксальному видообразованию, функционируют в высказывании в соответствии со своими акциональными свойствами; префигированные (превербные) глаголы при этом склонны интерпретироваться (но не обязательно делают это) как соотнесенные с пределом, поскольку префиксы (превербы) тяготеют к реализации функции телисизаторов (в первую очередь при взаимодействии с глаголами движения).

\section{5. Эмпирические подтверждения для предсказаний двухкомпонентной} модели вида

Ниже будут приведены некоторые факты и высказывания, служащие подтверждением сформулированным в разделе 4 положениям (1)-(4).

\section{1. Верификация положения о преимуществе суффиксального форманта} над префиксальным при синтетическом видообразовании

Верификации положения (1) служат, в частности, следующие наблюдения над индуцированными контактным влиянием изменениями в области выраже- 
ния видовых значений как в славянских языках под воздействием либо языков с иным видом - не «славянского типа» по Э. Далю (Dahl 1985), либо невидовых языков, так и с противоположным воздействием.

В (Breu, Pila, Scholze 2017), исследовании о контактных процессах в области вида в славянских микроязыках под воздействием доминантных романских или германских языков, находим следующее свидетельство: «В исследуемых славянских микроязыках в Италии (молизско-славянском, резьянском. - E.Г.), видовые пары предельных глаголов, заимствованных из романских языковых разновидностей, образуются исключительно с помощью суффиксов: в процессе заимствования итальянские глаголы сначала интегрируются в $\mathrm{CB}$, а для последующего образования соответствующего глагола НСВ служит именно суффиксация, например, в МСЯ (молизско-славянском языке. - Е.Г.): итал. fermare $>$ fermat $\mathrm{CB}$ 'остановить' $\rightarrow$ fermivat $\mathrm{HCB}$ 'останавливать'» (Ibid.: 63) (относительно интеграции непредельных глаголов: «[н]епредельные глаголы интегрируются как несоотносительные глаголы НСВ, напр., в МСЯ posedit 'иметь, обладать' < итал. possedere или pizat 'весить' < итал. pesare или же sumiljat 'быть похожим' < итал. somigliare, а в РЕ3 (резьянском. - E.Г.) baštet 'быть достаточным' < итал. bastare, фриул. bastâ. и somajet 'быть похожим' < итал. somigliare, фриул. someâ» (Ibid., footnote 12)). Отметим использование для создания видовой парадигмы именно суффиксации, а также акциональное обоснование (предельность / непредельность) для интеграции симплексов.

В том же исследовании находим еще одно косвенное свидетельство превалирования суффиксального способа кодирования аспекта (вида): «свойства имперфекта и перфекта МСЯ точно соответствуют употреблению имперфекта и перфекта в итальянском языке. Можно сказать, что флективная видовая оппозиция доминирует над деривационной оппозищией $\mathrm{HCB}$ : CB» (Breu, Pila, Scholze 2017: 68). Упомянутая «флективная видовая оппозиция» использует суффиксальные показатели.

Значимыми представляются также выводы другого авторского коллектива, исследовавшего видообразование заимствованных романских глаголов в резьянском микроязыке: «В отличие от суффиксации, которая является важнейшим способом грамматикализации глагольного вида у романских заимствованных (предельных) глаголов, способствуя образованию коррелята НСВ, префиксация (с противоположной функцией, т.е. создания коррелята СВ) играе весьма незначительную роль в этом процессе» (Benacchio, Steenwijk 2017: 34); «можно сказать, что в резьянском диалекте перфективирующая префиксация предельных глаголов романского происхождения явление редкое» (Ibid.: 35).

Невозможно, впрочем, не упомянуть, что авторы предлагают следующее объяснение полученному результату: «<...> носители резьянского диалекта, видимо, затруднялись присоединить к заимствованному глаголу морфологический элемент (префикс), который воспринимался как 'чуждый’ заимствующей языковой системе, в то время как имперфективирующая суффиксация считалась более приемлемой (возможно, и из-за того, что она напоминает окончания имперфекта территориально близких романских языков)» (Benacchio, Steenwijk 2017: 36). Думается, что можно предложить и иное объяснение: причина отмеченного предпочтения суффиксации кроется в том, что для видообразования было применено словоизменительное средство - регулярное и не изменяющее лексическую семантику, а не словообразовательное, с высокой вероятностью эту семантику модифицирующее.

Отметим также уже известную славянской аспектологии регулярность суффиксальной имперфективации болгарского языка, подтвержденную в исследовании С. Славковой на материале приставочных делимитативов: «Болгарские глаголы CВ, полученные путем присоединения делимитативного префикса по-, также образуют вторичный имперфектив: седянсв 'сидеть' > поседя св 'сидеть

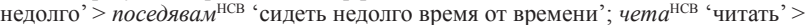

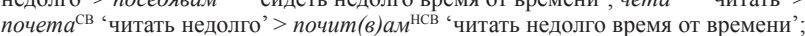

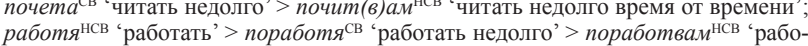
тать недолго время от времени' (Slavkova 2017: 202).

В завершении представления фактов, свидетельствующих о лучшей приспособленности суффиксального форманта к роли видообразующего показателя, упомянем мнение еще по крайней мере трех лингвистов, сходящихся в том, что славянский суффикс имперфективации, диахронически первичный, является наиболее регулярным морфологическим показателем. Ср. следующие утверждения: «[1]ate Common Slavic verb stems had the following basic structure: [PREFIX]-[ROOT]-[SUFFIX]» (Dickey 2017: 88); «[c] семантической точки зрения, суффиксы выполняли роль имперфективаторов, т.е. они служили представлению обозначенной глагольной основой ситуации в отвлечении от границ, либо заложенных, либо чисто временны́х $<\ldots>$. Эта функция сложилась, видимо, еще в общеславянский период, и это 'функциональное преемство' оказалось устойчивым на протяжении всех дальнейших периодов после того, как установилась телисизирующая префиксация» (Wiemer 2017: 232); «[п]о происхождению падать является древним итеративом по отношению к пасть, и, по-видимому, проделал ту же самую семантическую эволюцию, какая была характерна для всех итеративов, постепенно втягивавшихся в сферу вторичных имперфективов от предельных глаголов (как считается, этот процесс завершается как раз к XVIII - началу XIX вв.). В древнерусских памятниках глагол падати зафиксирован вполне надежно, и хорошо видно, что древнейшие примеры его употребления (первые фиксации - не позднее XIII века) отчетливо связаны с выражением не столько имперфективности, сколько глагольной множественности» (Plungjan 2017: 177).

Фальсифицируется положение (1) в случае обнаружения преимущества и большей (формальной и семантической) регулярности префиксов над суффиксами при видообразовании.

5.2. Верификация положения о принципиальной нерегулярности префиксального форманта как видового показателя и о необязательности его перфективирующего эффекта

С минимальными комментариями приведем некоторое количество фактов и выводов, сформулированных по результатам исследования приставочной перфективации, предоставив читателю возможность вынести собственные суждения.

Славистика XXIII/1 (2019) 
«В области морфологии необходимо подчеркнуть еще раз, что для образования видовых пар в современном резьянском микроязыке префиксация не является продуктивной. Как было упомянуто выше, префиксальные глаголы, образующие видовую пару с простым глаголом НCB, принадлежат, в основном, К исконно славянской лексике» (Breu, Pila, Scholze 2017: 73).

«Префиксы возникли из агглютинации некогда свободных морфем, уточняющих пространственную ориентацию. Эта довольно конкретная семантическая функция во многих языковых семьях превратилась в более абстрактную функцию введения внутреннего предела, т.е. приставки приобрели телисизирующую функцию. Однако в достаточно грамматикализованной системе распространение этой функции сопровождается развитием также и перфективирующей функции, согласно которой приставки приобретают способность обозначать всего лишь внешнее ограничение действия (или состояния). Важно, что перфективация происходит независимо от телисизации или от фокуса на лексически заложенном пределе» (Wiemer 2017: 230).

«[Ф]ункция перфективации, т. е. превращение глагола в терминативный, обозначающий реальное достижение предела, немецким префиксам в целом не свойственна» (Аркадьев 2015: 72); ср. также приведенное в конце раздела 2 свидетельство из (Андросюк 2015: 33) о биаспективном характере префигированных на русской почве заимствованных глаголов типа переквалифицировать.

Из исследования видовой системы в резьянском микроязыке (резьянском диалекте словенского языка) в (Benacchio, Steenwijk 2017). О видообразовании славянских глаголов: «[г]лагольные префиксы, помимо того, что превращаю глагол НСВ в глагол СВ, в большинстве случаев придают базовой форме определенное лексическое значение, и новый приставочный глагол обязан создать себе партнера с тем же значением посредством т. наз. вторичной имперфективации» (Ibid.: 26); о видообразовании у заимствованных романских глаголов «[3]аимствованные романские глаголы также проявляют тенденцию к созданию коррелята, т. е. к созданию видовой пары, выражающей СВ и НСВ (количество оставшихся 'неинтегрированными' биаспективных глаголов не столь большое). Однако они прибегают в основном к ... модели суффиксации и только в редких случаях к префиксации. Имеются в виду, естественно, только предельные глаголы, которые принадлежат к вендлеровским классам Accomplishments, Achievements и которые в грамматикализированной видовой славянской системе нуждаются в двух формах для выражения однократного действия, достигшего своего результата, и действия, находящегося в процессе осуществления или многократного действия. Непредельные глаголы (States и Activities), являющиеся imperfectiva tantum, такими и остаются. Только в редких случаях (как было замечено выше по поводу исконно славянской лексики) эти глаголы подвергаются префиксации для выражения способов действия (в основном начинательного и делимитативного)» (Ibid.: 33).

Из результатов исследования (Arkadiev 2017): о заимствовании славянских глагольных префиксов в идиш - признается слабая степень грамматикализации: префикс вносит соотнесенность с пределом, но не его достижение, т.е. имеет место телисизация, но не перфективация (Ibid.: 6); на материале цыганских идиомов (в частности, северо-русского, заимствовавшего глагольные префиксы из русского)
Двухкомпонентная модель русского вида: положсения, предсказания, подтверэсения

- признается факт заимствования русских глагольных префиксов, которые, однако, не стали перфективаторами (Ibid.: 8-9); на материале ливского языка (финноугорский идиом, длительный контакт с латышским), заимствовавшего глагольные префиксы из латышского - еще меньшая склонность к реализации аспектуальных значений, чем в латышском: их употребление «не приобрело ни систематического характера, ни, в еще меньшей степени, обязательности» (Ibid.: 10).

Более общее утверждение того же автора, сделанное на более широком материале типологически ориентированного исследования: «... в разных языках (и в разные периоды истории одного языка) разные превербы в большей или меньшей степени склонны к «чистой перфективации»» (Аркадьев 2015: 84)

Фальсифицируется положение (2) через обнаружение единого префиксального показателя (набора дополнительно распределенных показателей), в обязательном порядке выполняющего телисизирующую и перфективирующую функцию по отношению к исходным симплексам-имперфективам, и тем самым приобретающего регулярность.

\section{3. Верификация положения об автономном заимствовании префиксации и о более низком уровне грамматикализации префиксации в случае параллельного заимствования префиксации и суффиксации}

Так же, как и в предыдущем разделе, приведем ряд найденных в литературе свидетельств. Прежде всего, укажем, что взятые из (Arkadiev 2017) факты о заимствованиях префиксов в идиш, ливском и северно-русском цыганском «работают» и для верификации положения (3). Приведем также дополнительные наблюдения и выводы из литературы вопроса.

Истрорумынский язык (балкано-романская подгруппа романской группы) осуществил заимствование из славянских языков (хорватского) не только системы глагольных префиксов, но и суффикса-имперфективатора -ва-. При этом относительно результирующей системы, см. Таблицу 3 в (Arkadiev 2017: 12), можно утверждать, что она в значительной степени повторяет русскую систему при словоизменительной трактовке вида с суффиксальной морфологией, предложенной в (Горбова 2017б) и выше в разделе 3.

«Подытоживая, можно сказать, что различная роль приставок в доминирующих языках оказала очень серьезное влияние на видовые системы славянских микроязыков, как на формальном, так и на функциональном плане. В двух микроязыках, находящихся под романским влиянием (РЕЗ, МСЯ), префиксация утратила свою продуктивность для образования видовых пар, в то время как в двух микроязыках, находящихся под влиянием немецкого языка, префиксация является также и в заимствованных глаголах важным видовым формантом. Только в микроязыках под романским влиянием флективная оппозиция имперфект : перфект еще играет важную роль, однако только в МСЯ это происходит в полном соответствии с итальянской моделью, в то время как в современном PE3 имперфект утратил свои видовые функции в изъявительном наклонении. В инцептивно-статических глаголах преобладание романского видового типа особенно наглядно. Все четыре микроязыка формально сохранили деривационную оппозицию НСВ : СВ, но в ВРЯ (верхнелужицком разговорном языке- 
E.Г.) влияние приставок немецкого языка вызвало глубокую перестройку функциональной системы вида» (Breu, Pila, Scholze 2017: 80).

Положение (3) фальсифицируется посредством доказательства обязательности совместного заимствования обоих известных аспектуальных механизмов - суффиксации и префиксации при более высокой степени грамматикализации префиксального механизма.

5.4. Верификация положения о функционировании симплексов в соответствии с акциональностью и о необязательности телисизации и перфективации при префигировании

Приведем несколько положений, подтверждающих положение (4).

«В современном языке пасть несомненно относится к глаголам СВ, причем принадлежит к небольшому классу непроизводных бесприставочных перфективов (так называемых «перфективных симплексов»), насчитывающих всего около десятка лексем - таких, как сесть, лечь, стать, дать, деть и нек. др. Симплексы (т.е. глаголы с непроизводной основой, без префиксов и суффиксов) в подавляющем большинстве в современном русском языке имперфективны; перфективные же симплексы являются исторической аномалией, хотя и существуют во всех славянских языках (при этом их список пересекается лишь частично)» (Plungjan 2017: 171).

«И у исконно славянских глаголов можно наблюдать исчезновение некоторых приставочных видовых пар. Например, gledat '(по)смостреть' - двувидовой, в то время как pogledat выражает однократный способ глагольного действия, в смысле 'бросить взгляд'. Другой пример: pisat '(на)писать' - двувидовой, в то время как napisat выражает способ глагольного действия в значении 'написать слишком много'. В случае двувидового заимствования lejit '(про) читать' < итал. диал. lejje, приставочных форм вообще нет» (Breu, Pila, Scholze 2017: 66).

О префигированных глаголах в старославянском: «... prefixation does not create aspect pairs like suffixation does, because, although it creates a perfective verb, the original verb stays anaspectual» (Kamphuis 2017: 133).

Возможна также реализация другой, более экономной, стратегии: симплексы реализуются не как моно-, а как биаспективы: «Как глаголы исконно славянской лексики, например, vïdët ‘(у)видеть', čot ‘(у)слышать', так и заимствованные глаголы этого класса, например, kapet 'понимать / понять' < итал. capire, фриул. capî или plažät '(по)нравиться’ < фриул. plasê, в основном являются двувидовыми» (Breu, Pila, Scholze 2017: 74).

Положение (4) фальсифицируется обнаружением независимости результирующего аспектуального значения глагольного предиката-симплекса на уровне высказывания от его исходной акциональной характеристики, а также фактов обязательности телисизации и перфективации при префиксации глаголов.

\section{6. Итоги и перспективы}

В заключение вернемся к такой характеристике предлагаемой двухкомпонентной модели описания категории вида в русском языке, как бо́льшая типологическая предсказуемость категории. В этой связи отметим следующее.

Словоизменительный аспект (вид) для общей аспектологии является нормой, в отличие от явно отличающегося от этой нормы «вида славянского типа» по (Dahl 1985), типичным представителем которого является традиционная модель русского вида с ее утверждением о несловоизменительном характере этой категории. Принимая двухкомпонентную модель русского вида, мы получаем более гомогенную картину грамматической организации аспектуальной семантической зоны в языках мира.

Кроме того, заложенная в двухкомпонентной модели зависимость контекстуальных значений глаголов-симплексов, не имеющих специализированных аспектуальных показателей, от акциональности глагола (внутреннего контекста) и граммем времени, таксиса или адвербиалов (внешнего контекста), также является ожидаемым для естественного человеческого языка явлением.

В перспективе возможно более широкое применение двухкомпонентной модели за счет расширения материала до группы славянских языков, реализующих в своей аспектуальной семантической зоне так называемый «вид славянского типа» (по Э. Далю).

\section{Использованная литература}

Андросюк, Наталья В. «Биаспектив и контекст». [В:] Р. Бенаккьо (ред.). Глагольный вид: Грамматическое значение и контекст. Die Welt der Slaven: Sammelbände / Сборники. Bd. 56 (Hrsg. von P. Rehder und I. Smirnov). München - Berlin Washington/D.C.: Verlag Otto Sagner, 2015, 21-34.

Аркадьев, Петр М. Ареальная типология префиксального перфектива. Москва: Языки славянской культуры, 2015.

Горбова, Елена В. «Видообразование русского глагола: префиксация и/или суффиксация?». Вопросы языкознания 1, 2015: 7-37.

Горбова, Елена В. Грамматическая категория аспекта и контекст. Санкт-Петербург: Изд-во СПбГУ, 2017а.

Горбова, Елена В. «Русское видообразование: словоизменение, словоклассификация или набор квазиграммем? (еще раз о болевых точках русской аспектологии)». Вопросы языкознания 1, 2017б: 24-52.

Горбова, Елена В. «Имперфективируемость русских приставочных перфективов (на примере про- и $y$-глаголов)». Вопросы языкознания 1, 2019: 58-74.

Зализняк, Андрей А. Грамматический словарь русского языка. Словоизменение. Москва: Русский язык, 1977.

Иткин, Илья Б. «Можно ли определить вид русского глагола?». [В:] Л. А. Вербицкая (отв. ред). Научное наследие и развитие идей Юрия Сергеевича Маслова. Международная конференция (20-22.11.2014). Тезисы. Сост.: Н. В. Агеева, Е. А. Бабаина, Е. Л. 
Вилинбахова, О. Ю. Чуйкова. Санкт-Петербург: Изд-во СПбГУ, 2014, 84-86.

Мельчук, Игорь А. Курс общей морфологии. Т. 4. Часть пятая: Морфологические знаки. Москва - Вена: Языки славянской культуры, Венский славистический альманах, 2001.

Мучник, Иосиф П. Грамматические категории глагола и имени в современном русском литературном языке. Москва: Наука, 1971.

Перцов, Николай В. Инварианты в русском словоизменении. Москва: Языки русской культуры, 2001.

Пешковский, Алексей М. Русский синтаксис в научном освещении. Москва: Учпедгиз, 1956

Плунгян, Владимир А. Введение в грамматическую семантику: грамматические значения и грамматические системы языков мира. Москва: РГГУ. 2011.

РГ-1980: Русская грамматика (ред. Н. Ю. Шведова). Москва: Наука, 2005.

Смит, Карлота С. «Двухкомпонентная теория вида». [В:] М. Ю. Черткова (отв. ред.) Типология вида: проблемы, поиски, решения. Москва: Языки русской культуры, 1998, 404-422.

Хокинг, Стивен. Краткая история времени: От большого взрыва до черных дыр. Москва: Изд-во АСТ, 2018.

Arkadiev, Peter M. "Borrowed preverbs and the limits of contact-induced change in aspectual systems". [In:] Benacchio et al. (eds.) 2017, 1-22.

Benacchio, Rosanna, Muro, Alessio, Slavkova, Svetlana (eds.). The role of prefixes in the formation of Aspectuality. Issues of grammaticalization. Biblioteca di Studi Slavistici. V. 39. Firenze: Firenze University Press, 2017.

Benacchio, Rosanna, Steenwijk, Han. "Грамматикализация глагольного вида в резьянском диалекте: исконно славянская и романская лексика" [In:] Benacchio et al. (eds.) 2017, 23-40.

Breu, Walter, Pila, Malinka, Scholze, Lenka. “Видовые приставки в языковом контакте (на материале молизско-славянского, резьянского и верхнелужицкого микроязыков)" [In:] Benacchio et al. (eds.) 2017, 59-84.

Dahl, Östen. Tense and aspect systems. Oxford: Blackwell, 1985.

Dickey, Stephen M. "Prefixation in the Rise of Slavic Aspect". [In:] Benacchio et al (eds.) 2017, 85-102.

Kamphuis, Jaap. "The Role of Prefixation in Old Church Slavonic". [In:] Benacchio et al. (eds.) 2017, 115-136.

Plungjan, Vladimir A. "К списку двувидовых глаголов в русском языке: история nacmb". [In:] Benacchio et al. (eds.). 2017, 167-182.

Slavkova, Svetlana. "Супралексический префикс по- в русском и болгарском языках". [In:] Benacchio et al. (eds.) 2017, 197-218.

Smith, Carlota. The Parameter of Aspect. Dordrecht: Kluwer Academic Publishers 1991 2nd edition 1997.

Wiemer, Björn. "О роли приставок и суффиксов на ранних и поздних этапах истории славянского вида”. [In:] Benacchio et al. (eds.) 2017, 219-252.
Двухкомпонентная модель русского вида: положсения, предсказания, подтвержсения

Јелена В. Горбова

\section{ДВОКОМПОНЕНТНИ МОДЕЛ РУСКОГ ВИДА ПОСТАВКЕ, ПРОГНОЗЕ, ПОТВРДЕ}

Резиме

У раду је на позадини традиционалног - заснованог на класификацији речи - модела руског вида предложен алтернативни теоријски модел за дискусију, назван, по Карлоти Смит ског вида предложен алгерн као двокомпон ске радње, регуларност (у вези са добро познатом мена речи или класификација речи), морфолошки механизми образовања облика који се користе: суфиксација и префиксација. Важно место у грађењу алтернативног модела заузимају и аспектуално релевантне морфолошке и/или функционалне (под)класе глаголске лексике симплекси, моноаспективи, биаспективи, префиксални перфективи, секундарни имперфективи, као и секундарни перфективи као резултат вишеструке префиксације. Као ограничење за суфиксалну имперфективизацију прихваћена је забрана терцијарне имперфективизације коју је формулисао Сергеј Г. Татевосов.

Прва (и основна) компонента предложеног теоријског модела јесте морфолошки механизам имперфективно детерминисане суфиксације (у првом реду, једном) префигираних глаго-

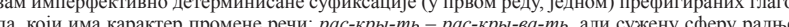
ла, који има карапер промене речи: рас-кры-ть-рас-кры-ва-пь, али сужену сферу радње.

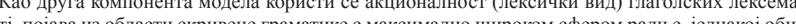

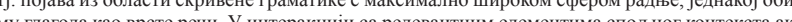

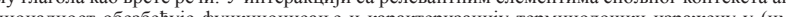
ционалнос обебе)уе фу й

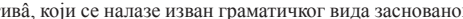
на промени речи.

Поред тога, у раду су формулисана уопштавања и прогнозе које произилазе из двокомпонентног модела вида руског глагола. Посебан одељак посвеһен је верификацији прогноза модела, изведеној на основу података из савремене аспектолошке и контактолошке научне литературе. Формулисани су и услови фалсификовања поставки предложеног теоријско модела. У закључку је дата карактеристика двокомпонентног модела руског вида са становишта опште (типолошки оријентисане) аспектологије. Поред осталог, показано је да предпожени теоријски модел анулира питане ексклузивности руског вида као посебног случај спенифичног жида словенскога типа“ у терминологији О. Дала. Анализа применљивост

Кључне речи: руски језик, вид (аспект), граматичка категорија, теоријски модел, промена речи, акционалност, моноаспектив, биаспектив, префиксални перфектив, секундарни имперфектив. 